\title{
Atendimento hospitalar aos equídeos de tração em Brasília
}

Letiana da Silva Rehbein ${ }^{[a]^{0}}$, Antonio Raphael Teixeira Neto ${ }^{[a]}$, Antonio Carlos Lopes Câmara ${ }^{[a]}$, Daniella Dianese Alves de Moraes $^{[b]}$

\author{
[a] Universidade de Brasília (UnB), Brasília, DF, Brasil

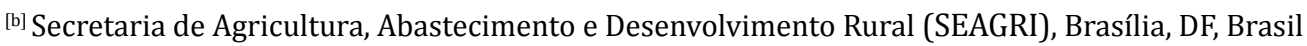

*Autor correspondente

e-mail: letianarehbein@gmail.com

\section{Resumo}

No Distrito Federal (DF) existem 1.700 equídeos de tração cadastrados na Secretaria de Agricultura, Abastecimento e Desenvolvimento Rural (SEAGRI), mas acredita-se que o total seja de três mil animais, visto que muitos optam pelo trabalho irregular. O Hospital Veterinário de Grandes Animais da Universidade de Brasília (HVet-UnB) recebe animais encaminhados pela SEAGRI, que podem ser: errantes; apreendidos por maus tratos pela polícia ambiental ou pelo Instituto Brasília Ambiental; com suspeita de doenças de notificação obrigatória, para isolamento; e soropositivos para anemia infecciosa equina (AIE), para eutanásia. Foi realizado um estudo retrospectivo do atendimento aos equídeos encaminhados pela SEAGRI ao HVet-UnB de janeiro de 2010 a julho de 2016. A coleta dos dados foi feita através da ata de registro e da ficha individual dos animais. Totalizaram-se 454, que representaram 41,84\% do total de 1.085 atendimentos a equídeos no HVet-UnB no período. Observou-se uma marcada diferença entre a quantidade de equinos (97\%), muares (2\%) e asininos (1\%). Tal fato difere do encontrado em um estudo em Alagoas, em que 76\% dos equídeos de tração urbana eram muares, $21 \%$ equinos e $3 \%$ asininos; a justificativa foi que os muares eram mais resistentes à jornada de trabalho e os jumentos seriam utilizados pela falta de oportunidade de possuir um equino ou muar, e sua baixa utilização seria pela preferência em mantê-los como reprodutores na produção de muares. No DF, a preferência por equinos dava-se por seu temperamento mais dócil e também para utilizá-los na reprodução. Com relação ao sexo, a quantidade de machos foi superior a de fêmeas: 59\% e 41\%, respectivamente. Essa informação também difere do encontrado no estudo em Alagoas, em que 86,32\% eram fêmeas e 13,68\% machos; justificou-se que a preferência ocorre porque fêmeas tem o temperamento mais dócil para trabalho e podem ser utilizadas na reprodução. Já no DF, os machos eram preferidos pois os condutores acreditavam que eles possuíam mais energia para o trabalho (principalmente 
os não castrados) e que as fêmeas, quando utilizadas na reprodução, precisavam ficar períodos sem trabalhar no final da gestação e início da amamentação. Excluindo-se os 43 animais soropositivos para AIE, observa-se que 193 (47\%) de um total de 411 animais vieram a óbito ou foram eutanasiados, 170 (41\%) receberam alta e $48(12 \%)$ não tinham informações nas respectivas fichas. Deve-se destacar ainda que entre os animais que receberam alta, muitos estavam inaptos para o trabalho, mesmo alguns jovens. Entre os fatores relacionados à rápida aposentadoria estão o manejo incorreto, alta quantidade de horas de trabalho por dia, muita carga tracionada e o fato desses animais serem introduzidos muito jovens ao trabalho, normalmente amansados após a primeira muda dentária, logo começando a tracionar as carroças. Desta maneira, fica claro como este trabalho é prejudicial. Na literatura encontrada, as principais medidas tomadas com relação à tração animal foram as palestras de informação e conscientização, que tentam melhorar as condições do tratamento dado aos equídeos e também aumentar as chances dos condutores encontrarem outras formas de sustento. As palestras são realizadas principalmente por voluntários e acadêmicos de instituições de ensino. 0 ideal seria um novo modo de sustento para carroceiros e o destino dos animais uma aposentadoria que lhes permita o bem-estar. Acredita-se que isso seja possível elevando as penas para maus tratos, impedindo que as pessoas que os cometem possam possuir novamente o animal maltratado, como também através da educação de jovens e de cursos de capacitação para adultos. Vale ressaltar que foi regulamentada em março de 2017 a lei distrital 2016-05756, que proíbe a circulação de veículos de tração animal em áreas urbanas e vias públicas pavimentadas, e veda a permanência desses animais soltos, peados, atados por cordas ou por outros meios de contenção, em vias ou em logradouros públicos do DF.

Palavras-chave: Tração animal. Bem-estar. Equídeo. 